Review

\title{
Hepatitis C Virus and Hepatocellular Carcinoma
}

\author{
Tatsuo Kanda $^{1, *}$, Osamu Yokosuka ${ }^{1}$ and Masao Omata ${ }^{2,3, *}$
}

1 Department of Gastroenterology and Nephrology, Graduate School of Medicine, Chiba University, 1-8-1 Inohana, Chuo-ku, Chiba 260-8670, Japan; E-Mail: yokosukao@faculty.chiba-u.jp

2 Yamanashi Hospitals (Central and Kita) Organization, 1-1-1 Fujimi, Koufu-shi, Yamanashi 400-8506, Japan

3 University of Tokyo, 7-3-1, Hongo, Bunkyo-ku, Tokyo 113-8655, Japan

* Author to whom correspondence should be addressed; E-Mails: kanda2t@yahoo.co.jp (T.K.); momata-tky@umin.ac.jp (M.O.); Tel.: +81-43-226-2086 (T.K.); Fax: +81-43-226-2088 (T.K.).

Received: 4 January 2013; in revised form: 18 January 2013 / Accepted: 23 January 2013 /

Published: 30 January 2013

\begin{abstract}
Hepatitis C virus (HCV), a hepatotropic virus, is a single stranded-positive RNA virus of $\sim 9,600 \mathrm{nt}$. length belonging to the Flaviviridae family. HCV infection causes acute hepatitis, chronic hepatitis, cirrhosis and hepatocellular carcinoma (HCC). It has been reported that HCV-coding proteins interact with host-cell factors that are involved in cell cycle regulation, transcriptional regulation, cell proliferation and apoptosis. Severe inflammation and advanced liver fibrosis in the liver background are also associated with the incidence of HCV-related HCC. In this review, we discuss the mechanism of hepatocarcinogenesis in HCV-related liver diseases.
\end{abstract}

Keywords: androgen receptor; apoptosis; gender difference; hepatitis C virus; hepatocellular carcinoma; inflammation

\section{Introduction}

Hepatitis $\mathrm{C}$ virus (HCV) infection affects 3-4 million people every year and $\sim 170$ million people are chronically infected with this virus [1]. HCV infection causes acute and chronic hepatitis, cirrhosis and hepatocellular carcinoma (HCC) [2]. Although peginterferon and ribavirin together with or without telaprevir or boceprevir are currently used for HCV infection, a significant number of infected 
individuals do not respond to this treatment $[3,4]$. As a result, more than 350,000 people die every year from HCV-related liver diseases such as cirrhosis and HCC [1].

$\mathrm{HCV}$ is a positive-sense single-stranded RNA virus belonging to the Flaviviridae family. The HCV genome is approximately 9,600 nt. in length and consists of a 5' nontranslated region (5' NTR), a single open reading frame that encodes a polyprotein precursor of about 3,000 amino acids, and a 3' NTR. Both structural (core, E1, E2, and p7) and nonstructural proteins (NS2, NS3, NS4A, NS4B, NS5A, and NS5B) are cleaved from the single open reading frame by both viral and host proteases $[5,6]$. The $\mathrm{HCV}$ genome also has an internal ribosomal entry site (IRES) that can promote 5'-end-independent initiation of RNA translation [7].

$\mathrm{HCV}$ proteins are reported to interact with host-cell factors that are involved in cell cycle regulation, transcriptional regulation, cell proliferation and apoptosis [8]. Severe inflammation and advanced liver fibrosis in the liver background are also associated with the incidence of HCV-related HCC $[9,10]$. In this review, we discuss the mechanism of hepatocarcinogenesis in HCV-related liver diseases.

\section{Signaling Pathways Affected by HCV Proteins}

\subsection{Signaling Pathways Involved in Hepatocarcinogenesis}

The molecular pathways to hepatocarcinogenesis involve many signaling pathways such as extracellular signal-regulated kinase [Erk: mitogen activated protein kinase (MAPK)], Wnt/ $\beta$-catenin, apoptosis, transforming growth factor-beta (TGF- $\beta$ ), phosphoinositide-3-kinase(PI3K)/Akt, mammalian target of rapamycin (mTOR), nuclear factor kappa-light-chain-enhancer of activated B cells (NF- $\kappa$ B), Hedgehog, p53, cytokine and sex steroid pathways [11] (Figure 1A). Unique pathways do not seem to contribute to hepatocarcinogenesis. $\mathrm{HCV}$ is an RNA virus, and it is thought to be unable to integrate its genome into the host genome, in contrast to hepatitis B virus (HBV) or human immunodeficiency virus (HIV). However, HCV proteins and the interaction between them and host proteins mainly contribute to the viral oncogenic processes $[8,12]$.

Figure 1. Signaling pathways affected by Hepatitis C virus (HCV) proteins. (a) Signaling pathways involved in hepatocarcinogenesis. (b) Signaling pathways affected by HCV core protein. (c) Signaling pathways affected by HCV NS5A protein.

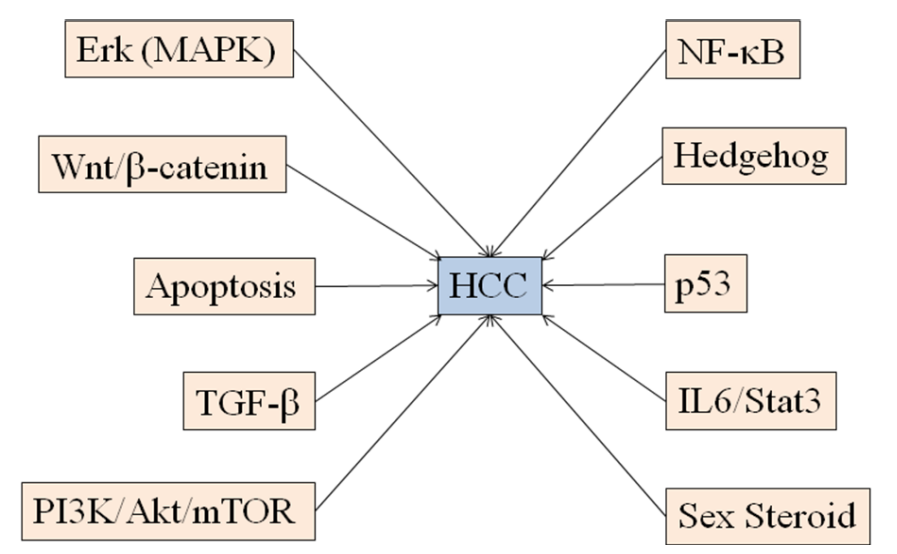


Figure 1. Cont.

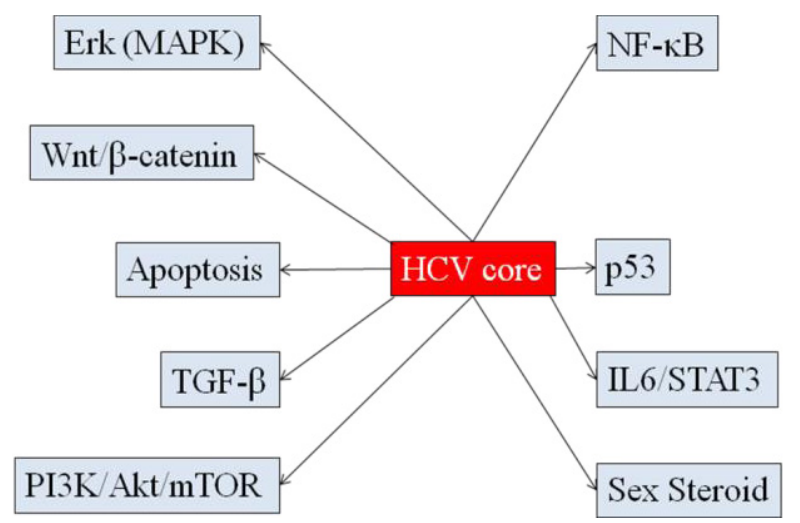

b

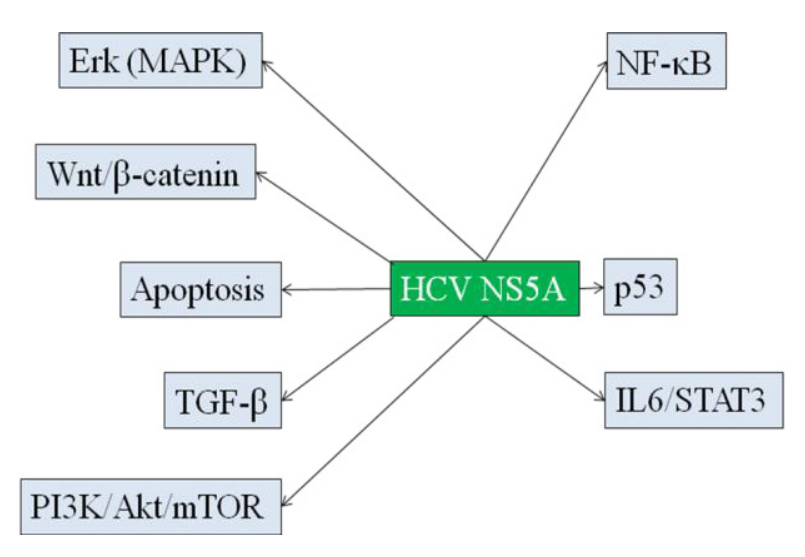

c

\subsection{Signaling Pathways Affected by HCV Core Protein}

$\mathrm{HCV}$ core protein is a basic protein that is thought to comprise the nucleocapside of $\mathrm{HCV}$, and its size is $17-23 \mathrm{kDa}$ [8]. Ray et al. [13] reported that HCV core protein has oncogenic potential. That is, $\mathrm{HCV}$ core protein cooperates with ras and transforms primary rat embryo fibroblasts to tumorigenic phenotype. HCV core protein can activate the Erk (MAPK) signaling pathway [13-18], upregulate Wnt/ $\beta$-catenin pathway [16,19], suppress apoptosis pathway [20-22], and activate TGF- $\beta$ [23,24], PI3K/Akt/mTOR [25-29], NF-кB [30-32], p53 [33-35], IL-6/Stat3 [36-38] and androgen receptor (AR) pathways [39] (Figure 1B). Through these pathways, cell growth, differentiation, apoptosis, transcription and angiogenesis might be regulated by HCV core protein.

$\mathrm{HCV}$ core might represent a novel type of Raf-1 kinase-activating protein through $\mathrm{HCV}$ core-14-3-3 protein interaction and contribute to hepatocyte growth regulation [14]. HCV core can directly activate the MAPK cascade and prolong its activity in response to mitogenic stimuli, contributing to the neoplastic transformation of $\mathrm{HCV}$-infected liver cells [16]. HCV core protein promotes proliferation of human hepatoma cells by activation of MAPK pathway via up-regulation of TGF $\alpha$ transcription by activation of NF- $\kappa B$ [18]. HCV core interacts with NF- $\mathrm{BB}$ signaling pathway [30-32]. HCV core protein promotes hepatocyte growth at least partly through transcriptional upregulation of growth-related genes, and in particular Wnt [19].

HCV infection is associated with hepatocyte cell death such as apoptosis [20-22] and autophagy [40]. The ability of core protein to inhibit the TNF-mediated apoptotic signaling pathway may provide a selective advantage for HCV replication [20,22]. HCV core also inhibits Fas-mediated apoptotic cell death via a mechanism dependent on the activation of NF- $\kappa B$ [21]. HCV core protein expression may directly upregulate TGF-beta 1 transcription in hepatocytes [23]. HCV core protein activates Akt through the Ras/PI(3)K pathway [25-29]. HCV core protein may also play an important biological role in the promotion of cell growth by repressing p53 transcription [33]. Further, HCV core protein acts as an effector in the promotion of cell growth by repressing p21 transcription [34]. HCV core protein may directly influence the various p73 functions, playing a role in HCV pathogenesis [41] (Table 1). 
Table 1. HCV proteins core and NS5A, and apoptosis.

\begin{tabular}{|c|c|c|}
\hline HCV protein & Host protein interacted with HCV protein [Reference] & Action \\
\hline core & $\begin{array}{c}\text { TNF receptor-1 [42], NF-кB [21], TRADD, TRAF [43], pRb [44], p73 [41], } \\
\text { 14-3-3epsilon [45], Hsp60 [46], Mcl-1 [47] }\end{array}$ & pro-apoptosis \\
\hline core & $\begin{array}{c}\text { NF- } \kappa B \text { [48], p38 MAPK [49], Bcl-x [50], p53 [51], p73 [41], Inhibitor of } \\
\text { caspase-activated DNase [52], p21, Bcl-2 [53], Apaf-1, E2F1 [54], } \\
\text { Grp78/Bip, Grp94 [55], PML [56], Stat3 [37], cFLIP [22], DR5 [57] }\end{array}$ & anti-apoptosis \\
\hline NS5A & $\operatorname{Bax}[58]$ & pro-apoptosis \\
\hline NS5A & $\begin{array}{l}\text { PKR, eIF-2alpha [59], TRADD [60], p53 [61,62], Grb2 [63], PI3K [63,64], } \\
\text { NF-кB [65], Bin1 [66], FKBp38 [67,68], calpain cystein protease, Bid [69], } \\
\text { Kv2.1 [70], TLR4 [71] }\end{array}$ & anti-apoptosis \\
\hline
\end{tabular}

HCV core-induced Stat3 activation also plays an important role in hepatocarcinogenesis [35-38]. HCV core protein enhances vascular endothelial growth factor (VEGF) expression and facilitates angiogenesis in the presence of AR and acts as a positive regulator in AR signaling [39].

\subsection{Signaling Pathways Affected by HCV NS5A Protein}

HCV NS5A exists as two phosphoproteins, p56 and p58, phosphorylated at serine residues after the mature protein is released from the polyprotein [72]. HCV NS5A plays a critical role in the perturbation of MAPK signaling pathways in HCV-infected hepatocytes [73]. HCV NS5A activates $\beta$-catenin signaling cascades by increasing its stability [74], and HCV NS5A protein interacts with $\beta$-catenin and stimulates its transcriptional activity in a PI3K-dependent fashion $[75,76]$. HCV NS5A protein protects against LPS [71] or TNF- $\alpha$-mediated apoptotic cell death [60,77] (Table 1). Further, HCV NS5A activates TGF- $\beta$ signaling [78,79], induces EMT and participates in oncogenic transformation of primary hepatocyte precursors and in mouse hepatic progenitors along with cooperative oncogene H-RasV12 [80]. HCV NS5A also activates PI3K/Akt/mTOR pathway [63,64,68,81] and NF-kB signaling [82-85]. In addition, HCV NS5A physically associates with p53 and regulates p21/waf1 gene expression in a p53-dependent manner [86-88]. HCV NS5A-mediated Stat3 activation requires co-operation of Jak1 kinase [82,89] (Figure 1C). HCV NS5A induces a range of liver pathology including HCC in transgenic mice [90], although HCV NS5A transgenic animals are also valuable models of $\mathrm{HCV}$ immunopathology [91]. HCV probably does not induce HCC in transgenic mice $[4,60,88,91,92]$.

\subsection{Signaling Pathways Affected by other HCV Proteins}

Several studies have reported that cell transformation was induced by HCV NS3 proteins [93,94]. JNK activation is essential for the stimulation of HCV NS3-mediated cell growth [95]. The $N$-terminal portion of NS3 forms a complex with the tumor suppressor p53 and suppresses actinomycin D-induced apoptosis [96]. There have been several reports regarding other HCV proteins interacting with host proteins and suggesting that these might lead to hepatocarcinogenesis [97-99]. 


\subsection{HCV-Associated Inflammation Induces HCC}

Takano et al. prospectively investigated the incidence of $\mathrm{HCC}$ in 124 cases of hepatitis $\mathrm{C}$ and found that HCC occurred in 13 chronic hepatitis C cases, consisting of 12 cirrhotic livers and only 1 non-cirrhotic liver [9]. A recent study with transient elastography also supports this observation [100]. Several lines of evidence $[10,101]$ support the concept that HCV-associated inflammation causes HCC. Chronic HCV infection represents the increases in endoplasmic reticulum (ER) stress and oxidative stress [102-107]. The accumulation of unfolded proteins in ER causes ER stress and the unfolded protein response (UPR), mediated by the ER-resident stress sensors ATF-6, IRE1, and PERK, and the genes involved in the control of diffuse processes such as liver proliferation, inflammation, and apoptosis were significantly induced in chronic hepatitis C patients [102-106]. Increased hepatic iron deposition is common in $\mathrm{HCV}$-infected patients. Excessive iron is known to generate ROS within hepatocytes, causing mutagenic lesions such as 8-hydroxy-2'-deoxyguanosine (8-OHdG) in DNA. Long-term iron depletion by phlebotomy for chronic hepatitis $\mathrm{C}$ patients is a promising modality for lowering the risk of progression to HCC [108-111]. The prevalence of steatosis in $\mathrm{HCV}$-infected patients is $\sim 70 \%$. Age at liver biopsy, body mass index (BMI) and duration of $\mathrm{HCV}$ were independent risk factors for increased fibrosis in HCV patients. Steatosis as a risk factor for fibrosis is evident in genotype-1 [112]. Nieminen et al. [112] recommended that the degree of steatosis be evaluated in addition to fibrosis and inflammation activity. It seems important that activating survival genes within cancer cells and inflammation-promoting genes in components of the tumor microenvironment may be important for the development of HCC [113]. Further studies will be needed for clarification.

\section{Conclusions}

$\mathrm{HCV}$ is a major risk factor for the development of HCC and there is increasing experimental evidence to suggest that the virus plays a direct role in neoplastic transformation. We reviewed the literature regarding two individual proteins of $\mathrm{HCV}$, namely core and NS5A, and their role in the pathogenesis of HCC through perturbations of cellular pathways, in addition to their immunopathological effects of chronic inflammation. Inflammation as well as ER stress, oxidative stress, iron overload and steatosis in hepatocytes are also important factors (Figure 2). Not only eradication of HCV but also corrections of these factors play important roles in the prevention of the development of HCC.

Figure 2. Development of hepatocellular carcinoma (HCC) after HCV infection.

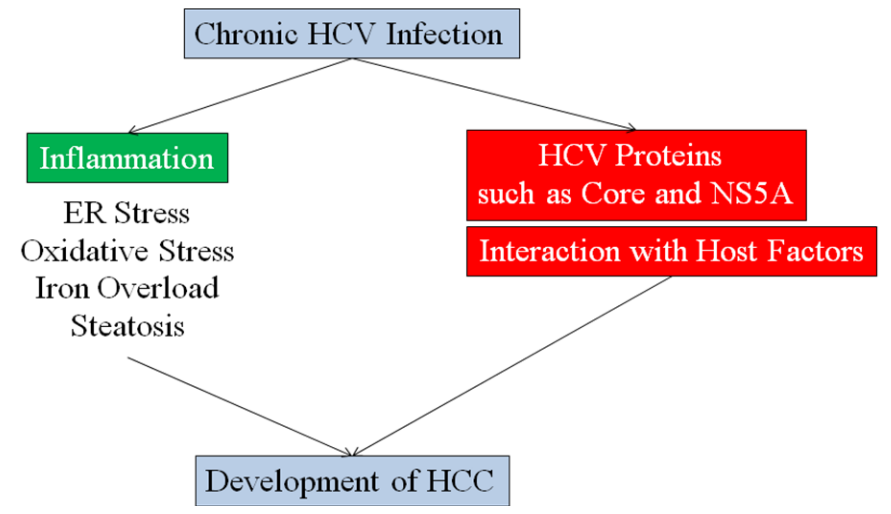




\section{References and Notes}

1. Hanafiah, K.M.; Groegar, J.; Flaxman, A.D.; Wiersma, S.T. Global epidemiology of hepatitis C virus infection: New estimates of age-specific antibody to hepatitis $\mathrm{C}$ virus seroprevalence. Hepatology 2012, doi:10.1002/hep.26141.

2. Di Bisceglie, A.M. Hepatitis C and hepatocellular carcinoma. Hepatology 2012, 26, 34S-38S.

3. Kanda, T.; Imazeki, F.; Yokosuka, O. New antiviral therapies for chronic hepatitis C. Hepatol. Int. 2010, 4, 548-561.

4. Omata, M.; Kanda, T.; Yu, M.L.; Yokosuka, O.; Lim, S.G.; Jafri, W.; Tateishi, R.; Hamid, S.S.; Chuang, W.L.; Chutaputti, A.; et al. APASL consensus statements and management algorithms for hepatitis C virus infection. Hepatol. Int. 2012, 6, 409-435.

5. Tanaka, T.; Kato, N.; Cho, M.J.; Sugiyama, K.; Shimotohno, K. Structure of the 3' terminus of the hepatitis C virus genome. J. Virol. 1996, 70, 3307-3312.

6. Kanda, T.; Steele, R.; Ray, R.; Ray, R.B. Inhibition of intrahepatic gamma interferon production by hepatitis $\mathrm{C}$ virus nonstructural protein 5A in transgenic mice. J. Virol. 2009, 83, 8463-8469.

7. Honda, M.; Brown, E.A.; Lemon, S.M. Stability of a stem-loop involving the initiator AUG controls the efficiency of internal initiation of translation on hepatitis $\mathrm{C}$ virus RNA. RNA 1996, 2, 955-968.

8. Banerjee, A.; Ray, R.B.; Ray, R. Oncogenic potential of hepatitis C virus proteins. Viruses 2010, 2, 2108-2133.

9. Takano, S.; Yokosuka O.; Imazeki, F.; Tagawa, M.; Omata, M. Incidence of hepatocellular carcinoma in chronic hepatitis B and C: A prospective study of 251 patients. Hepatology 1995, $21,650-655$.

10. Tarao, K.; Rino, Y.; Ohkawa, S.; Shimizu, A.; Tamai, S.; Miyakawa, K.; Aoki, H.; Imada, T.; Shindo, K.; Okamoto, N.; Totsuka, S. Association between high serum alanine aminotransferase levels and more rapid development and higher rate of incidence of hepatocellular carcinoma in patients with hepatitis C virus-associated cirrhosis. Cancer 1999, 86, 589-595.

11. Kanda, T.; Imazeki, F.; Kanai, F.; Tada, M.; Yokosuka, O.; Omata, M. Signaling pathways involved in molecular carcinogenesis of hepatocellular carcinoma. In Molecular Aspects of Hepatocellular Carcinoma; Qiao, L., George, J., Li, Y., Yan, X., Eds.; Bentham Science: Oak Park, IL, USA, 2012; pp. 39-55.

12. Tsai, W.L.; Chung, R.T. Viral hepatocarcinogenesis. Oncogene 2010, 29, 2309-2324.

13. Ray, R.B.; Lagging, L.M.; Meyer, K.; Ray, R. Hepatitis C virus core protein cooperates with ras and transforms primary rat embryo fibroblasts to tumorigenic phenotype. J. Virol. 1996, 70, $4438-4443$.

14. Aoki, H.; Hayashi, J.; Moriyama, M.; Arakawa, Y.; Hino, O. Hepatitis C virus core protein interacts with 14-3-3 protein and activates the kinase Raf-1. J. Virol. 2000, 74, 1736-1741.

15. Hayashi, J.; Aoki, H.; Kajino, K.; Moriyama, M.; Arakawa, Y.; Hino, O. Hepatitis C virus core protein activates the MAPK/ERK cascade synergistically with tumor promoter TPA, but not with epidermal growth factor or transforming growth factor alpha. Hepatology 2000, 32, 958-961. 
16. Giambartolomei, S.; Covone, F.; Levrero, M.; Balsano, C. Sustained activation of the $\mathrm{Raf} / \mathrm{MEK} /$ Erk pathway in response to EGF in stable cell lines expressing the Hepatitis C Virus (HCV) core protein. Oncogene 2001, 20, 2606-2610.

17. Spaziani, A.; Alisi, A.; Sanna, D.; Balsano, C. Role of p38 MAPK and RNA-dependent protein kinase (PKR) in hepatitis $\mathrm{C}$ virus core-dependent nuclear delocalization of cyclin B1. J. Biol. Chem. 2006, 281, 10983-10989.

18. Sato, Y.; Kato, J.; Takimoto, R.; Takada, K.; Kawano, Y.; Miyanishi, K.; Kobune, M.; Takayama, T.; Matunaga, T.; Niitsu, Y. Hepatitis $\mathrm{C}$ virus core protein promotes proliferation of human hepatoma cells through enhancement of transforming growth factor alpha expression via activation of nuclear factor-kappaB. Gut 2006, 55, 1801-1808.

19. Fukutomi, T.; Zhou, Y.; Kawai, S.; Eguchi, H.; Wands, J.R.; Li, J. Hepatitis C virus core protein stimulates hepatocyte growth: Correlation with upregulation of wnt-1 expression. Hepatology 2005, 41, 1096-1105.

20. Ray, R.B.; Meyer, K.; Steele, R.; Shrivastava, A.; Aggarwal, B.B.; Ray, R. Inhibition of tumor necrosis factor (TNF-alpha)-mediated apoptosis by hepatitis $\mathrm{C}$ virus core protein. J. Biol. Chem. 1998, 273, 2256-2259.

21. Marusawa, H.; Hijikata, M.; Chiba, T.; Shimotohno, K. Hepatitis C virus core protein inhibits Fas- and tumor necrosis factor alpha-mediated apoptosis via NF-kappaB activation. J. Virol. 1999, 73, 4713-4720.

22. Saito, K.; Meyer, K.; Warner, R.; Basu, A.; Ray, R.B.; Ray, R. Hepatitis C virus core protein inhibits tumor necrosis factor alpha-mediated apoptosis by a protective effect involving cellular FLICE inhibitory protein. J. Virol. 2006, 80, 4372-4379.

23. Taniguchi, H.; Kato, N.; Otsuka, M.; Goto, T.; Yoshida, H.; Shiratori, Y.; Omata, M. Hepatitis C virus core protein upregulates transforming growth factor-beta 1 transcription. J. Med. Virol. 2004, 72, 52-59.

24. Pavio, N.; Battaglia, S.; Boucreux, D.; Arnulf, B.; Sobesky, R.; Hermine, O.; Brechot, C. Hepatitis $\mathrm{C}$ virus core variants isolated from liver tumor but not from adjacent non-tumor tissue interact with Smad3 and inhibit the TGF-beta pathway. Oncogene 2005, 24, 6119-6132.

25. Waris, G.; Felmlee, D.J.; Negro, F.; Siddiqui, A. Hepatitis C virus induces proteolytic cleavage of sterol regulatory element binding proteins and stimulates their phosphorylation via oxidative stress. J. Virol. 2007, 81, 8122-8130.

26. Miyamoto, H.; Moriishi, K.; Moriya, K.; Murata, S.; Tanaka, K.; Suzuki, T.; Miyamura, T.; Koike, K.; Matsuura, Y. Involvement of the PA28gamma-dependent pathway in insulin resistance induced by hepatitis C virus core protein. J. Virol. 2007, 81, 1727-1735.

27. Banerjee, S.; Saito, K.; Ait-Goughoulte, M.; Meyer, K.; Ray, R.B.; Ray, R. Hepatitis C virus core protein upregulates serine phosphorylation of insulin receptor substrate-1 and impairs the downstream akt/protein kinase B signaling pathway for insulin resistance. J. Virol. 2008, 82, 2606-2612.

28. Nakamura, H.; Aoki, H.; Hino, O.; Moriyama, M. HCV core protein promotes heparin binding EGF-like growth factor expression and activates Akt. Hepatol. Res. 2011, 41, 455-462. 
29. Bose, S.K.; Shrivastava, S.; Meyer, K.; Ray, R.B.; Ray, R. Hepatitis C virus activates the $\mathrm{mTOR} / \mathrm{S} 6 \mathrm{~K} 1$ signaling pathway in inhibiting IRS-1 function for insulin resistance. J. Virol. 2012, 86, 6315-6322.

30. Shrivastava, A.; Manna, S.K.; Ray, R.; Aggarwal, B.B. Ectopic expression of hepatitis C virus core protein differentially regulates nuclear transcription factors. J. Virol. 1998, 72, 9722-9728.

31. Yoshida, H.; Kato, N.; Shiratori, Y.; Otsuka, M.; Maeda, S.; Kato, J.; Omata, M. Hepatitis C virus core protein activates nuclear factor kappa B-dependent signaling through tumor necrosis factor receptor-associated factor. J. Biol. Chem. 2001, 276, 16399-16405.

32. Ray, R.B.; Steele, R.; Basu, A.; Meyer, K.; Majumder, M.; Ghosh, A.K.; Ray, R. Distinct functional role of Hepatitis $\mathrm{C}$ virus core protein on NF-kappaB regulation is linked to genomic variation. Virus Res. 2002, 87, 21-29.

33. Ray, R.B.; Steele, R.; Meyer, K.; Ray, R. Transcriptional repression of p53 promoter by hepatitis C virus core protein. J. Biol. Chem. 1997, 272, 10983-10986.

34. Ray, R.B.; Steele, R.; Meyer, K.; Ray, R. Hepatitis C virus core protein represses p21WAF1/Cip1/Sid1 promoter activity. Gene 1998, 208, 331-336.

35. Otsuka, M.; Kato, N.; Lan, K.; Yoshida, H.; Kato, J.; Goto, T.; Shiratori, Y.; Omata, M. Hepatitis $\mathrm{C}$ virus core protein enhances p53 function through augmentation of DNA binding affinity and transcriptional ability. J. Biol. Chem. 2000, 275, 34122-34130.

36. Yoshida, T.; Hanada, T.; Tokuhisa, T.; Kosai, K.; Sata, M.; Kohara, M.; Yoshimura, A. Activation of STAT3 by the hepatitis C virus core protein leads to cellular transformation. J. Exp. Med. 2002, 196, 641-653.

37. Basu, A.; Meyer, K.; Lai, K.K.; Saito, K.; di Bisceglie, A.M.; Grosso, L.E.; Ray, R.B.; Ray, R. Microarray analyses and molecular profiling of Stat 3 signaling pathway induced by hepatitis $\mathrm{C}$ virus core protein in human hepatocytes. Virology 2006, 349, 347-358.

38. Tacke, R.S.; Tosello-Trampont, A.; Nguyen, V.; Mullins, D.W.; Hahn, Y.S. Extracellular hepatitis $\mathrm{C}$ virus core protein activates STAT3 in human monocytes/macrophages/dendritic cells via an IL-6 autocrine pathway. J. Biol. Chem. 2011, 286, 10847-10855.

39. Kanda, T.; Steele, R.; Ray, R.; Ray, R.B. Hepatitis C virus core protein augments androgen receptor-mediated signaling. J. Virol. 2008, 82, 11066-11072.

40. Ait-Goughoulte, M.; Kanda, T.; Meyer, K.; Ryerse, J.S.; Ray, R.B.; Ray, R. Hepatitis C virus genotype 1a growth and induction of autophagy. J. Virol. 2008, 82, 2241-2249.

41. Alisi, A.; Giambartolomei, S.; Cupelli, F.; Merlo, P.; Fontemaggi, G.; Spaziani, A.; Balsano, C. Physical and functional interaction between $\mathrm{HCV}$ core protein and the different p73 isoforms. Oncogene 2003, 22, 2573-2580.

42. Zhu, N.; Khoshnan, A.; Schneider, R.; Matsumoto, M.; Dennert, G.; Ware, C.; Lai, M.M. Hepatitis $\mathrm{C}$ virus core protein binds to the cytoplasmic domain of tumor necrosis factor (TNF) receptor 1 and enhances TNF-induced apoptosis. J. Virol. 1998, 72, 3691-3697.

43. Park, K.J.; Choi, S.H.; Koh, M.S.; Kim, D.J.; Yie, S.W.; Lee, S.Y.; Hwang, S.B. Hepatitis C virus core protein potentiates c-Jun $N$-terminal kinase activation through a signaling complex involving TRADD and TRAF2. Virus Res. 2001, 74, 89-98. 
44. Cho, J.; Baek, W.; Yang, S.; Chang, J.; Sung, Y.C.; Suh, M. HCV core protein modulates Rb pathway through pRb down-regulation and E2F-1 up-regulation. Biochim. Biophys. Acta. 2001, 1538, 59-66.

45. Lee, S.K.; Park, S.O.; Joe, C.O.; Kim, Y.S. Interaction of HCV core protein with 14-3-3epsilon protein releases Bax to activate apoptosis. Biochem. Biophys. Res. Commun. 2007, 352, 756-762.

46. Kang, S.M.; Kim, S.J.; Kim, J.H.; Lee, W.; Kim, G.W.; Lee, K.H.; Choi, K.Y.; Oh, J.W. Interaction of hepatitis $\mathrm{C}$ virus core protein with Hsp60 triggers the production of reactive oxygen species and enhances TNF-alpha-mediated apoptosis. Cancer Lett. 2009, 279, 230-237.

47. Mohd-Ismail, N.K.; Deng, L.; Sukumaran, S.K.; Yu, V.C.; Hotta, H.; Tan, Y.J. The hepatitis C virus core protein contains a $\mathrm{BH} 3$ domain that regulates apoptosis through specific interaction with human Mcl-1. J. Virol. 2009, 83, 9993-10006.

48. Tai, D.I.; Tsai, S.L.; Chen, Y.M.; Chuang, Y.L.; Peng, C.Y.; Sheen, I.S.; Yeh, C.T.; Chang, K.S.; Huang, S.N.; Kuo, G.C.; et al. Activation of nuclear factor kappaB in hepatitis C virus infection: Implications for pathogenesis and hepatocarcinogenesis. Hepatology 2000, 31, 656-664.

49. Takamatsu, M.; Fujita, T.; Hotta, H. Suppression of serum starvation-induced apoptosis by hepatitis C virus core protein. Kobe J. Med. Sci. 2001, 47, 97-112.

50. Otsuka, M.; Kato, N.; Taniguchi, H.; Yoshida, H.; Goto, T.; Shiratori, Y.; Omata, M. Hepatitis C virus core protein inhibits apoptosis via enhanced Bcl-xL expression. Virology 2002, 296, 84-93.

51. Basu, A.; Meyer, K.; Ray, R.B.; Ray, R. Hepatitis C virus core protein is necessary for the maintenance of immortalized human hepatocytes. Virology 2002, 298, 53-62.

52. Sacco, R.; Tsutsumi, T.; Suzuki, R.; Otsuka, M.; Aizaki, H.; Sakamoto, S.; Matsuda, M.; Seki, N.; Matsuura, Y.; Miyamura, T.; et al. Antiapoptotic regulation by hepatitis $\mathrm{C}$ virus core protein through up-regulation of inhibitor of caspase-activated DNase. Virology 2003, 317, 24-35.

53. Kim, J.S.; Ryu, J.; Hwang, S.B.; Lee, S.Y.; Choi, S.Y.; Park, J. Suppression of ceramide-induced cell death by hepatitis C virus core protein. J. Biochem. Mol. Biol. 2004, 37, 192-198.

54. Meyer, K.; Basu, A.; Saito, K.; Ray, R.B.; Ray, R. Inhibition of hepatitis C virus core protein expression in immortalized human hepatocytes induces cytochrome c-independent increase in Apaf-1 and caspase-9 activation for cell death. Virology 2005, 336, 198-207.

55. Benali-Furet, N.L.; Chami, M.; Houel, L.; de Giorgi, F.; Vernejoul, F.; Lagorce, D.; Buscail, L.; Bartenschlager, R.; Ichas, F.; Rizzuto, R.; Paterlini-Brechot, P. Hepatitis C virus core triggers apoptosis in liver cells by inducing ER stress and ER calcium depletion. Oncogene 2005, 24, 4921-4933.

56. Herzer, K.; Weyer, S.; Krammer, P.H.; Galle, P.R.; Hofmann, T.G. Hepatitis C virus core protein inhibits tumor suppressor protein promyelocytic leukemia function in human hepatoma cells. Cancer Res. 2005, 65, 10830-10837.

57. Du, J.; Liang, X.; Liu, Y.; Qu, Z.; Gao, L.; Han, L.; Liu, S.; Cui, M.; Shi, Y.; Zhang, Z.; et al. Hepatitis B virus core protein inhibits TRAIL-induced apoptosis of hepatocytes by blocking DR5 expression. Cell Death Differ. 2009, 16, 219-229.

58. Chung, Y.L.; Sheu, M.L.; Yen, S.H. Hepatitis C virus NS5A as a potential viral Bcl-2 homologue interacts with Bax and inhibits apoptosis in hepatocellular carcinoma. Int. J. Cancer 2003, 107, 65-73. 
59. Gale, M., Jr.; Kwieciszewski, B.; Dossett, M.; Nakao, H.; Katze, M.G. Antiapoptotic and oncogenic potentials of hepatitis $\mathrm{C}$ virus are linked to interferon resistance by viral repression of the PKR protein kinase. J. Virol. 1999, 73, 6506-6516.

60. Majumder, M.; Ghosh, A.K.; Steele, R.; Zhou, X.Y.; Phillips, N.J.; Ray, R.; Ray, R.B. Hepatitis $\mathrm{C}$ virus NS5A protein impairs TNF-mediated hepatic apoptosis, but not by an anti-FAS antibody, in transgenic mice. Virology 2002, 294, 94-105.

61. Lan, K.H.; Sheu, M.L.; Hwang, S.J.; Yen, S.H.; Chen, S.Y.; Wu, J.C.; Wang, Y.J.; Kato, N.; Omata, M.; Chang, F.Y.; et al. HCV NS5A interacts with p53 and inhibits p53-mediated apoptosis. Oncogene 2002, 21, 4801-4811.

62. Jiang, Y.F.; He, B.; Li, N.P.; Ma, J.; Gong, G.Z.; Zhang, M. The oncogenic role of NS5A of hepatitis $\mathrm{C}$ virus is mediated by up-regulation of survivin gene expression in the hepatocellular cell through p53 and NF-kappaB pathways. Cell Biol. Int. 2011, 35, 1225-1232.

63. He, Y.; Nakao, H.; Tan, S.L.; Polyak, S.J.; Neddermann, P.; Vijaysri, S.; Jacobs, B.L.; Katze, M.G. Subversion of cell signaling pathways by hepatitis $\mathrm{C}$ virus nonstructural 5A protein via interaction with Grb2 and P85 phosphatidylinositol 3-kinase. J. Virol. 2002, 76, 9207-9217.

64. Street, A.; Macdonald, A.; Crowder, K.; Harris, M. The Hepatitis C virus NS5A protein activates a phosphoinositide 3-kinase-dependent survival signaling cascade. J. Biol. Chem. 2004, 279, 12232-12241.

65. Bonte, D.; Francois, C.; Castelain, S.; Wychowski, C.; Dubuisson, J.; Meurs, E.F.; Duverlie, G. Positive effect of the hepatitis $\mathrm{C}$ virus nonstructural $5 \mathrm{~A}$ protein on viral multiplication. Arch. Virol. 2004, 149, 1353-1371.

66. Nanda S.K.; Herion, D.; Liang, T.J. The SH3 binding motif of HCV [corrected] NS5A protein interacts with Bin1 and is important for apoptosis and infectivity. Gastroenterology 2006, 130, 794-809.

67. Wang, J.; Tong, W.; Zhang, X.; Chen, L.; Yi, Z.; Pan, T.; Hu, Y.; Xiang, L.; Yuan, Z. Hepatitis $\mathrm{C}$ virus non-structural protein NS5A interacts with FKBP38 and inhibits apoptosis in Huh7 hepatoma cells. FEBS Lett. 2006, 580, 4392-4400.

68. Peng, L.; Liang, D.; Tong, W.; Li, J.; Yuan, Z. Hepatitis C virus NS5A activates the mammalian target of rapamycin (mTOR) pathway, contributing to cell survival by disrupting the interaction between FK506-binding protein 38 (FKBP38) and mTOR. J. Biol. Chem. 2010, 285, 20870-20881.

69. Simonin, Y.; Disson, O.; Lerat, H.; Antoine, E.; Biname, F.; Rosenberg, A.R.; Desagher, S.; Lassus, P.; Bioulac-Sage, P.; Hibner, U. Calpain activation by hepatitis C virus proteins inhibits the extrinsic apoptotic signaling pathway. Hepatology 2009, 50, 1370-1379.

70. Norris, C.A.; He, K.; Springer, M.G.; Hartnett, K.A.; Horn, J.P.; Aizenman, E. Regulation of neuronal proapoptotic potassium currents by the hepatitis $\mathrm{C}$ virus nonstructural protein 5A. J. Neurosci. 2012, 32, 8865-8870.

71. Tamura, R.; Kanda, T.; Imazeki, F.; Wu, S.; Nakamoto, S.; Tanaka, T.; Arai, M.; Fujiwara, K.; Saito, K.; Roger, T.; et al. Hepatitis C Virus nonstructural 5A protein inhibits lipopolysaccharide-mediated apoptosis of hepatocytes by decreasing expression of Toll-like receptor 4. J. Infect. Dis. 2011, 204, 793-801. 
72. Tanji, Y.; Kaneko, T.; Satoh, S.; Shimotohno, K. Phosphorylation of hepatitis C virus-encoded nonstructural protein NS5A. J. Virol. 1995, 69, 3980-3986.

73. Macdonald, A.; Crowder, K.; Street, A.; McCormick, C.; Saksela, K.; Harris, M. The hepatitis C virus non-structural NS5A protein inhibits activating protein-1 function by perturbing ras-ERK pathway signaling. J. Biol. Chem. 2003, 278, 17775-17784.

74. Milward, A.; Mankouri, J.; Harris, M. Hepatitis C virus NS5A protein interacts with beta-catenin and stimulates its transcriptional activity in a phosphoinositide-3 kinase-dependent fashion. J. Gen. Virol. 2010, 91, 373-381.

75. Park, C.Y.; Choi, S.H.; Kang, S.M.; Kang, J.I.; Ahn, B.Y.; Kim, H.; Jung, G.; Choi, K.Y.; Hwang, S.B. Nonstructural 5A protein activates beta-catenin signaling cascades: Implication of hepatitis C virus-induced liver pathogenesis. J. Hepatol. 2009, 51, 853-864.

76. Street, A.; Macdonald, A.; McCormick, C.; Harris, M. Hepatitis C virus NS5A-mediated activation of phosphoinositide 3-kinase results in stabilization of cellular beta-catenin and stimulation of beta-catenin-responsive transcription. J. Virol. 2005, 79, 5006-5016.

77. Ghosh, A.K.; Majumder, M.; Steele, R.; Meyer, K.; Ray, R.; Ray, R.B. Hepatitis C virus NS5A protein protects against TNF-alpha mediated apoptotic cell death. Virus Res. 2000, 67, 173-178.

78. Choi, S.H.; Hwang, S.B. Modulation of the transforming growth factor-beta signal transduction pathway by hepatitis C virus nonstructural 5A protein. J. Biol. Chem. 2006, 281, 7468-7478.

79. Presser, L.D.; Haskett, A.; Waris, G. Hepatitis C virus-induced furin and thrombospondin-1 activate TGF-beta1: Role of TGF-beta1 in HCV replication. Virology 2011, 412, 284-296.

80. Akkari, L.; Gregoire, D.; Floc'h, N.; Moreau, M.; Hernandez, C.; Simonin, Y.; Rosenberg, A.R.; Lassus, P.; Hibner, U. Hepatitis C viral protein NS5A induces EMT and participates in oncogenic transformation of primary hepatocyte precursors. J. Hepatol. 2012, 57, 1021-1028.

81. Cheng, D.; Zhao, L.; Zhang, L.; Jiang, Y.; Tian, Y.; Xiao, X.; Gong, G. P53 controls hepatitis C virus nonstructural protein 5A-mediated down-regulation of GADD45 $\alpha$ expression via the NF-кB and PI3K-Akt pathways. J. Gen. Virol. 2012, doi:10.1099/vir.0.046052-0.

82. Gong, G.; Waris, G.; Tanveer, R.; Siddiqui, A. Human hepatitis C virus NS5A protein alters intracellular calcium levels, induces oxidative stress, and activates STAT-3 and NF-kappa B. Proc. Natl. Acad. Sci. USA 2001, 98, 9599-9604.

83. Park, K.J.; Choi, S.H.; Lee, S.Y.; Hwang, S.B.; Lai, M.M. Nonstructural 5A protein of hepatitis $\mathrm{C}$ virus modulates tumor necrosis factor alpha-stimulated nuclear factor kappa B activation. J. Biol. Chem. 2002, 277, 13122-13128.

84. Waris, G.; Tardif, K.D.; Siddiqui, A. Endoplasmic reticulum (ER) stress: Hepatitis C virus induces an ER-nucleus signal transduction pathway and activates NF-kappaB and STAT-3. Biochem. Pharmacol. 2002, 64, 1425-1430.

85. Waris, G.; Livolsi, A.; Imbert, V.; Peyron, J.F.; Siddiqui, A. Hepatitis C virus NS5A and subgenomic replicon activate NF-kappaB via tyrosine phosphorylation of IkappaBalpha and its degradation by calpain protease. J. Biol. Chem. 2003, 278, 40778-40787.

86. Ghosh, A.K.; Steele, R.; Meyer, K.; Ray, R.; Ray, R.B. Hepatitis C virus NS5A protein modulates cell cycle regulatory genes and promotes cell growth. J. Gen. Virol. 1999, 80, 1179-1183. 
87. Ghosh, A.K.; Majumder, M.; Steele, R.; Yaciuk, P.; Chrivia, J.; Ray, R.; Ray, R.B. Hepatitis C virus NS5A protein modulates transcription through a novel cellular transcription factor SRCAP. J. Biol. Chem. 2000, 275, 7184-7188.

88. Majumder, M.; Ghosh, A.K.; Steele, R.; Ray, R.; Ray, R.B. Hepatitis C virus NS5A physically associates with p53 and regulates p21/wafl gene expression in a p53-dependent manner. J. Virol. 2001, 75, 1401-1407.

89. Sarcar, B.; Ghosh, A.K.; Steele, R.; Ray, R.; Ray, R.B. Hepatitis C virus NS5A mediated STAT3 activation requires co-operation of Jak1 kinase. Virology 2004, 322, 51-60.

90. Wang, A.G.; Lee, D.S.; Moon, H.B.; Kim, J.M.; Cho, K.H.; Choi, S.H.; Ha, H.L.; Han, Y.H.; Kim, D.G.; Hwang, S.B.; et al. Non-structural 5A protein of hepatitis $\mathrm{C}$ virus induces a range of liver pathology in transgenic mice. J. Pathol. 2009, 219, 253-262.

91. Majumder, M.; Steele, R.; Ghosh, A.K.; Zhou, X.Y.; Thornburg, L.; Ray, R.; Phillips, N.J.; Ray, R.B. Expression of hepatitis $\mathrm{C}$ virus non-structural $5 \mathrm{~A}$ protein in the liver of transgenic mice. FEBS Lett. 2003, 555, 528-532.

92. Honda, A.; Arai, Y.; Hirota, N.; Sato, T.; Ikegami, J.; Koizumi, T.; Hatano, M.; Kohara, M.; Moriyama, T.; Imawari, M.; et al. Hepatitis C virus structural proteins induce liver cell injury in transgenic mice. J. Med. Virol. 1999, 59, 281-289.

93. Sakamuro, D.; Furukawa, T.; Takegami, T. Hepatitis C virus nonstructural protein NS3 transforms NIH 3T3 cells. J. Virol. 1995, 69, 3893-3896.

94. Zemel, R.; Gerechet, S.; Greif, H.; Bachmatove, L.; Birk, Y.; Golan-Goldhirsh, A.; Kunin, M.; Berdichevsky, Y.; Benhar, I.; Tur-Kaspa, R. Cell transformation induced by hepatitis $\mathrm{C}$ virus NS3 serine protease. J. Viral Hepat. 2001, 8, 96-102.

95. Hassan, M.; Ghozlan, H.; Abdel-Kader, O. Activation of c-Jun NH2-terminal kinase (JNK) signaling pathway is essential for the stimulation of hepatitis $\mathrm{C}$ virus (HCV) non-structural protein 3 (NS3)-mediated cell growth. Virology 2005, 333, 324-336.

96. Tanaka, M.; Nagano-Fujii, M.; Deng, L.; Ishido, S.; Sada, K.; Hotta, H. Single-point mutations of hepatitis C virus NS3 that impair p53 interaction and anti-apoptotic activity of NS3. Biochem. Biophys. Res. Commun. 2006, 340, 792-799.

97. Lee, S.H.; Kim, Y.K.; Kim, C.S.; Seol, S.K.; Kim, J.; Cho, S.; Song, Y.L.; Bartenschlager, R.; Jang, S.K. E2 of hepatitis C virus inhibits apoptosis. J. Immunol. 2005, 175, 8226-8235.

98. Foy, E.; Li, K.; Wang, C.; Sumpter, R., Jr.; Ikeda, M.; Lemon, S.M.; Gale, M., Jr. Regulation of interferon regulatory factor-3 by the hepatitis C virus serine protease. Science 2003, 300, $1145-1148$.

99. Moriyama, M.; Kato, N.; Otsuka, M.; Shao, R.X.; Taniguchi, H.; Kawabe, T.; Omata, M. Interferon-beta is activated by hepatitis C virus NS5B and inhibited by NS4A, NS4B, and NS5A. Hepatol. Int. 2007, 1, 302-310.

100. Masuzaki, R.; Tateishi, R.; Yoshida, H.; Goto, E.; Sato, T.; Ohki, T.; Imamura, J.; Goto, T.; Kanai, F.; Kato, N.; et al. Prospective risk assessment for hepatocellular carcinoma development in patients with chronic hepatitis C by transient elastography. Hepatology 2009, 49, 1954-1961.

101. Sahasrabuddhe, V.V.; Gunja, M.Z.; Graubard, B.I.; Trabert, B.; Schwartz. L.M.; Park, Y.; Hollenbeck, A.R.; Freedman, N.D.; McGlynn, K.A. Nonsteroidal Anti-inflammatory Drug Use, Chronic Liver Disease, and Hepatocellular Carcinoma. J. Natl. Cancer Inst. 2012, 104, 1808-1814. 
102. Shuda, M.; Kondoh, N.; Imazeki, N.; Tanaka, K.; Okada, T.; Mori, K.; Hada, A.; Arai, M.; Wakatsuki, T.; Matsubara, O.; et al. Activation of the ATF6, XBP1 and grp78 genes in human hepatocellular carcinoma: A possible involvement of the ER stress pathway in hepatocarcinogenesis. J. Hepatol. 2003, 38, 605-614.

103. Asselah, T.; Bieche, I.; Mansouri, A.; Laurendeau, I.; Cazals-Hatem, D.; Feldmann, G.; Bedossa, P.; Paradis, V.; Martinot-Peignoux, M.; Lebrec, D.; et al. In vivo hepatic endoplasmic reticulum stress in patients with chronic hepatitis C. J. Pathol. 2010, 221, 264-274.

104. Merquiol, E.; Uzi, D.; Mueller, T.; Goldenberg, D.; Nahmias, Y.; Xavier, R.J.; Tirosh, B.; Shibolet, O. HCV causes chronic endoplasmic reticulum stress leading to adaptation and interference with the unfolded protein response. PLoS One 2011, 6, e24660.

105. Ke, P.Y.; Chen, S.S. Hepatitis C virus and cellular stress response: Implications to molecular pathogenesis of liver diseases. Viruses 2012, 4, 2251-2290.

106. Huang, H.; Kang, R.; Wang, J.; Luo, G.; Yang, W.; Zhao, Z. Hepatitis C virus inhibits AKT-tuberous sclerosis complex (TSC), the mechanistic target of rapamycin (MTOR) pathway, through endoplasmic reticulum stress to induce autophagy. Autophagy 2012, 9, 175-195.

107. Tsukiyama-Kohara, K. Role of oxidative stress in hepatocarcinogenesis induced by hepatitis C virus. Int. J. Mol. Sci. 2012, 13, 15271-15278.

108. Kato, J.; Kobune, M.; Nakamura, T.; Kuroiwa, G.; Takada, K.; Takimoto, R.; Sato, Y.; Fujikawa, K.; Takahashi, M.; Takayama, T.; et al. Normalization of elevated hepatic 8-hydroxy-2'deoxyguanosine levels in chronic hepatitis $\mathrm{C}$ patients by phlebotomy and low iron diet. Cancer Res. 2001, 61, 8697-8702.

109. Kato, J.; Miyanishi, K.; Kobune, M.; Nakamura, T.; Takada, K.; Takimoto, R.; Kawano, Y.; Takahashi, S.; Takahashi, M.; Sato, Y.; et al. Long-term phlebotomy with low-iron diet therapy lowers risk of development of hepatocellular carcinoma from chronic hepatitis C. J. Gastroenterol. 2007, 42, 830-836.

110. Liu, H.; Trinh, T.L.; Dong, H.; Keith, R.; Nelson, D.; Liu, C. Iron regulator hepcidin exhibits antiviral activity against hepatitis C virus. PLoS One 2012, 7, e46631.

111. Abd Elmonem, E.; Tharwa, S.; Farag, M.A.; Fawzy, A.; El Shinnawy, S.F.; Suliman, S. Hepcidin mRNA level as a parameter of disease progression in chronic hepatitis $\mathrm{C}$ and hepatocellular carcinoma. J. Egypt. Natl. Canc. Inst. 2009, 21, 333-342.

112. Nieminen, U.; Arkkila, P.E.; Karkkainen, P.; Farkkila, M.A. Effect of steatosis and inflammation on liver fibrosis in chronic hepatitis C. Liver Int. 2009, 29,153-158.

113. DiDonato, J.A.; Mercurio, F.; Karin, M. NF-kappaB and the link between inflammation and cancer. Immunol. Rev. 2012, 246, 379-400.

(C) 2013 by the authors; licensee MDPI, Basel, Switzerland. This article is an open access article distributed under the terms and conditions of the Creative Commons Attribution license (http://creativecommons.org/licenses/by/3.0/). 